\title{
Criteria of Ideal English Language Teachers as Perceived by Secondary and Tertiary Indonesian Students
}

\author{
Nur Salam ${ }^{*}$, Aulia Nourma Putri ${ }^{1}$, Tundung Subali Patima ${ }^{1}$, Azmi Abdul \\ Latiff $^{2}$, Ainul Azmin Md Zamin ${ }^{3}$
}

\author{
${ }^{1}$ State Polytechnic of Malang, INDONESIA \\ ${ }^{2}$ Centre for Language Studies, \\ Universiti Tun Hussein Onn Malaysia, MALAYSIA \\ ${ }^{3}$ Department of English and Literature, \\ International Islamic University, MALAYSIA \\ *Corresponding Author
}

DOI: https://doi.org/10.30880/jstard.2020.02.03.022

Received 30 September 2020; Accepted 30 November 2020; Available online 31 December 2020

\begin{abstract}
This study presents English teachers' professional, personality, social, leadership, and classroom interaction attributes which senior high school and university students expect from their English teachers. By knowing those attributes, English teachers are expected to be able to help their students attain better English language proficiency. For the investigation, five sets of questions were distributed in order to find out the respondents' favourite English teachers attributes. The respondents consisted of senior students of three high schools and undergraduates of three universities who had high, mediocre and low English language proficiency. The results show that the students' levels of education and English language proficiency influence the students' perceptions on their English teachers' attributes. This study suggests that English teachers recognize the attributes that their students highly expect from them. It is suggested that English teacher training institutions should conduct more professional English language and language teaching trainings that help teachers to develop the attributes. It is also suggested that the Ministry of Research, Technology and Higher Education of the Republic of Indonesia to monitor and evaluate universities and institutions which establish English Education Departments.
\end{abstract}

Keywords: Ideal English teachers, secondary school education, tertiary education, English teachers' attributes

\section{Introduction}

The issue of ideal teachers as perceived by students has been widely discussed in many conferences and written in many educational journal articles all over the world. This is because ideal teachers are believed to be able to create effective teaching which is responsive to the students' learning processes (Rice, 2003 and Moreno, 2010). In turns, effective teaching can bring the students' academic success (Polk, 2006; Danili \& Reid, 2006; Goe 2007 and Rockoff et al., 2008). The ideas on ideal teachers are always different from one time to another, from one place to another and from one culture to another. After reading the characteristics of ideal teachers, not only novice but also experienced teachers ask themselves whether or not they can belong to ideal teachers.

Wenglinsky (2000); Rice (2003) and Onike (2010) discovered that there are various factors which determine the extent students' perceptions of the teachers' attributes. These include the amount of their teachers' knowledge (Onike, 2010). Experience and paper qualifications (Rice, 2003) and also the teachers' methods of teaching. (Wenglinsky, 
2000).

However, there are some common attributes which can be associated with the characteristics of ideal teachers such as the teachers' study background, culture, experience, requirements, beliefs and principles. Kennedy (1997) stated that good teaching depends largely not only on the teachers' ability to explain their subjects but also on the ability to keep their students orderly and attentive in the classrooms. This idea is in correlated with Rice's idea (2003) which explained that teachers' coursework in their subject area and pedagogy bring positive education outcomes.

Teachers who apply effective and efficient teaching in their classes might produce high quality students (Kennedy, 1997). This idea is also in line with Wenglinsky (2000) who highlighted ideal teachers as those who are successfully able to make their students learn better. Onike (2010) stated that besides having to develop their competences and teaching strategies, ideal teachers should also have an appropriate training (Mundry, 2005; Quick et al., 2009 and Hunzicker, 2010) and have communication skills (Wayne \& Young, 2003; Danili \& Reid, 2006 and Rockoff et al., 2008). All qualities of ideal teachers also apply to English teachers.

Okoro and Chukwudi (2011) said that teachers are considered ideal if they can fulfill five interrelating categories: 1) professional attributes, 2) personality attributes, 3) social attributes, 4) leadership attributes, and 5) classroom interaction attributes. They believed that in order to have professional attribute, teachers should undergo professional trainings so that they have sufficient knowledge and skills of the subjects they are teach. They should also master the subject matter so that they can successfully trasfer it to their students (Polk, 2006; Danili \& Reid, 2006; Goe, 2007 and Rockoff et al., 2008). The teachers should always upgrade their subject matter by attending seminars, workshops and conferences (Porter et al., 2003; King \& Newmann, 2004; Mundry, 2005; Quick et al., 2009; Hunzicker, 2010; Moreno, 2010 and Liakopoulou, 2011). Then, they should learn how to improve their teaching from their more experienced colleagues. In other words, the teachers should be willing to change their ways of teaching when they see other teachers having better ways and be willing to study more when they still have less knowledge compared to others'. Having professional attributes will enable them to help students reach a better academic achievement (King \& Newmann, 2004; Mundry, 2005; Quick et al., 2009; Hunzicker, 2010; Moreno, 2010 and Liakopoulou, 2011).

Since the studies described above had not completely discussed the ideal teachers of English as perceived by the students, the present researchers need to conduct this research. In the present researchers' preliminary study, they found that twenty students out of twentyfour proposed to have a certain teacher whom they thought can help them understand the subject they were learning. In some schools, where the researchers conducted the preliminary study, the students' proposal described above can be fulfilled though the schools have their own ways. One of the ways is that the study program lists the teachers who will teach a certain subject completed with the days and the time the teachers will teach. Besides, the study program also informs the number of students who can take a certain teacher's class. Since the number of students who will take the subject is very big, the students should register their names by putting their names in the list. This means that the students actually can choose the teacher whom they like to teach them in their class.

This present research tries to know the perceptions of students from their different levels of educations towards their English teachers because the result of the preliminary study conducted by the researchers showed that the ideal teachers' attributes expected by university students and by the students of senior high schools are quite different. One of the differences is that most of the university students prefer to have English teachers who are highly qualified but most of Senior High School students admire to have English teachers who are communicative. That's why the researchers think that it is very important to know the ideal teachers' attributes seen from the students' different levels of educations.

Besides, the researchers also think that it is very important to find the English teachers' attributes perceived by the students who have different levels of their English proficiencies. It is again based on the result of the researchers' preliminary study which says that most of the students with low English proficiency expect to have English teachers who are patient in their teaching, the students with mediocre English proficiency prefer to be taught by English teachers who are humorous but those with high English proficiency expect to have English teachers who are creative. In other words, this present research is more complete than the previous research because it involves the students from different levels of educations and English proficiencies. These views become very important because the study can figure out the ideal teachers of English which are really expected by Indonesian students of senior high schools and universities with different levels of English proficiencies.

The reason why the researcher chose the students from different levels of educations was that he wanted to know whether there were any differences and similarities between their perceptions on their English teachers. Besides that, he also involved the students from different levels of English proficiencies. This involvement was intended to know which English teachers they preferred to teach them. Based on Okoro \& Chukwudi (2011) and Rice (2003), the present researcher constructed the indicators of teachers' attributes and used them in the in-depth interviews and in analyzing the data obtained. These ideas lead the researcher to propose the following research question: "What professional, personality, social, leadership, and classroom interaction attributes do the senior high school and university students who have high, mediocre and low English proficiencies expect from their English teachers?"

By knowing the students expectations, English teachers could prepare themselves better such as by up-grading their English knowledge and teaching method, planning their teaching and learning activities, preparing suitable teaching materials and appropriate teaching methods, motivating their students to study the lessons more seriously, 
managing their English classes, building good relationships with their students, giving feedbacks on their students' work and finally helping their students reach better English proficiencies.

\section{Methodology \\ Research Instruments}

The research instruments were developed as follows: Firstly, all questions related to the data needed to answer all research problems were constructed in Indonesian language by referring to the teachers' attributes introduced by Okoro \& Chukwudi (2011). The questions were presented in Indonesian version to make the interviews run naturally and in order to get comprehensive answers. In addition, the translation of the interviews was done by one the researchers, Aulia Nourma Putri, who teaches Translation in the English Department of State Polytechnic of Malang. Before the interviews were applied, they were validated by Nur Salam, a senior English teacher who teaches not only Translation but also Theory of Translation and Vocational Study Program of Brawijaya University. Secondly, those questions were listed and grouped according to the categories of English teachers' attributes, i.e.: professional, personality, social, leadership and classroom interaction attributes. Thirdly, those questions were tried out to the students involved in the preliminary study. Fourthly, the questions which were not understood by the students were revised and given back to the students till all questions were understood and their expected answers would not cause biases.

\section{Respondents}

The informants involved in this study were selected from the students of all departments (Language, Social Sciences, and Natural Sciences Departments) of the three senior high schools and of three universities. Since it was a case study, the informants were not selected based on sampling but on the researcher's own criteria. In other words, the researchers use a method of purposive sampling. In this case, the researcher asked for a help from the principals of the three senior high schools and from the heads of the three departments, i.e.: Language, Social Sciences, and Natural Sciences Departments from the three universities chosen to select their students who were considered very serious in their study. Their seriousness was seen from their regular class attendance, active participation in the class discussion, and their intensity in studying English outside the class-room. Besides, the students chosen as the informants of this study should belong to one of the groups of students with high, mediocre, and low English proficiencies. These levels of English proficiencies are based on their Grade Point Average during their study in universities or in polytechnics.

To be more specific, the principals of the three senior high schools and the heads of the three departments of the three universities gave lists of five names of students for each group that were selected into only one for each. The first selection the researcher did was that the researcher checked the students' Academic Grade Reports in their school or faculty offices. These records were used to ensure whether they were the right students to be informants in terms of their levels of educations and their levels of English proficiencies. In this step, they all fulfilled the requirements determined by the researcher as the informants. By doing so, the researcher found informants from different levels of educations (senior high school and university students), from different departments (Language, Social Sciences and Natural Sciences) and from different levels of English proficiencies (high, mediocre and low).

\section{Data Collection}

The researcher first arranged to visit the academic advisors of the informants and asked for copies of the informants' academic reports and any other written materials describing the informants' English proficiencies. Then, he reviewed the purpose of the study with the entire academic advisors and informants, scheduled individual interview times with all selected informants, asked for their email addresses and hand-phone numbers, and requested them all be cooperative and answered the questions frankly and freely, and responded to the additional written questions which were emailed when he needed further explanation. These written questions were used to crosscheck their answers in the interview session. Besides that, he took notes and recorded field notes after the interviews were completed. The interviews, although open-ended, were structured around the research questions defined at the start of the case study.

\section{Data Analysis}

The researchers examined the raw data in the forms of spoken answers gained from the in-depth interviews and of written descriptions got from the informants' responses to the written questions in order to find linkages between the research objects and the outcomes with reference to the original research questions. It was done by recording the informants' responses on the questions raised by the researchers. If the researchers failed to understand the responses, they asked the respondents to write their answers. When their responses were understood, the researchers grouped the responses into the teachers' attributes. Then, the researchers tried to find the theories which could support or decline the responses. Throughout the evaluation and analysis process, they remained open to new opportunities and insights. The case study method, with its use of multiple data collection methods and analysis techniques, provided them with opportunities to triangulate data in order to strengthen the research findings and conclusions. 
Then, the researchers categorized and recombined the data to address the initial purpose of the study,and conducted cross-checks of facts and discrepancies in accounts. If the two sets of data were contradictory or were not clear enough, the focused, short, repeat interviews might be necessary to gather additional data to check their real perceptions on English teachers' attributes. To be more specific, the researchers took five steps, which they created by themselves by referring to their preliminary study. These five steps proved to be effective and efficient in finding the teachers' attributes expected by the students. The five steps meant above are as follow: 1) understanding the data, 2) looking at how all informants responded to each question, 3) organizing the data into categories, 4) identifying patterns and connections within and between categories, and 5) interpreting the data.

\section{Findings}

\section{The Professional Attributes the Students Expected from English Teachers}

Basically all senior high school and university students agreed that professional trainings were very important for English teachers but they had different reasons. University students with low English proficiency (USLs) suggested that English teachers take professional trainings because these trainings were believed to be able to increase their knowledge of English so that they could improve their teaching method. In turns, they would be able to help their students achieve better English proficiency. Further they claimed that besides joining professional trainings, English teachers could improve their English and English teaching by learning with their more experienced colleagues.

However, university students with mediocre English proficiency (USMs) thought that professional trainings such as English language and language teaching seminars would be very much benefiting only for those who presented their papers. That was why they suggested that their English teachers take higher formal education. In addition, they suggested that the novice English teachers invite more experienced and successful colleagues to watch their teachings in the classrooms or sit in their more senior teachers' English classes and take ICT (Information and Communication Technology) courses.

Then, university students with high English proficiency (USHs) added some points that professional trainings could help English teachers improve their teaching methods, English language skills and increase their motivation in teaching. Besides by joining professional trainings, they said that English teachers could increase their teaching professionalism by attending seminars and by reading books, academic articles and journals on English language and teachings.

The ideas that professional trainings could help English teachers increase their English knowledge and improve their English language skills were in line with those stated by senior high school students with high English proficiency (SSHs) though they had different reasons. They recommended that all English teachers take professional trainings in order to be able to improve their English knowledge, to master various teaching methods and to construct good English tests. Then, they suggested that their English teachers study with the other more experienced English teachers, take a higher education and watch videos on ELT (English Language Teaching) in addition to taking professional trainings.

While senior high school students with mediocre English proficiency (SSMs) claimed that professional trainings enabled them to practice and develop their ability to listen to, read, speak and write in English. In addition, these professional trainings could give English teachers opportunities to observe other more experienced and successful teachers teaching their students. Besides by attending professional trainings, they claimed that English teachers could increase their English knowledge and teaching abilities by attending seminars and by reading English newspapers or magazines.

The last one, senior high school students with low English proficiency (SSLs) thought that attending professional trainings could improve their English speaking skills, English pronunciation and general communication. However, joining these professional trainings was not the only one way which could improve the teachers' English skills. The other ways were attending seminars and watching VCD of successful teachers' explaining the lesson.

\section{The Personality Attributes the Students Expected from English Teachers}

USHs perceived positively English teachers who were: highly qualified, creative, resourceful, well-prepared and fair. However, USMs did not completely agree with those USHs' ideas. The only English teachers' personality attribute they highly perceived was highly qualified. The other four personality attributes that USMs expected from their English teachers were enthusiastic, motivating, committed and communicative. Meanwhile, USLs admired English teachers who were qualified, caring, humorous, communicative and fair.

From the description above, the researcher found that only one English teachers' personality attribute, i.e. being highly qualified was positively perceived and put it in the first rank by all university students although they had different reasons. While the teachers' personality attribute admired by USHs and USLs was being fair. Those two groups agreed to put that attribute in the fifth rank. The last English teachers' personality attribute believed to be able to increase the students' motivation to study English harder by USMs and USLs was communicative. The only difference was on its positions, i.e. USMs put this English teachers' personality attribute in the fifth rank but USLs put it in the fourth one. 
However, SSHs expected from English teachers were: qualified, creative, communicative, fair and well-organized. The English teachers' attributes highly perceived by SSHs above were not completely admired by SSMs. There were two English teachers' personality attributes which those two groups expected, i.e.: qualified and communicative. In addition, both groups put qualified in the first rank but communicative was put in the third rank by SSHs and in the fourth one by SSMs. Then the other three English teachers' personality attributes which SSMs perceived positively were motivating (in the second rank), committed (in the fourth one) and respectful (in the fifth one).

If SSHs and SSMs' ideas above are compared with SSLs', we will see the similarities and differences. The similarities are as follows: SSHs, SSMs and SSLs positively perceived the English teachers' personality attribute called qualified. It happened that all of them put this English teachers' personality attribute in the first rank. Besides, SSMs and SSLs expected English teachers to be communicative and put this personality attribute in the fourth rank. In addition, SSLs admired their English teachers to be fair as SSHs did. The difference is on the rank where they put it. SSHs put it in the fourth rank but SSLs put it in the fifth. The last one, SSLs claimed that English teachers who were caring and humorous could help the students get better achievements. That is why they put caring in the second rank and humorous in the third one.

\section{The Social Attributes the Students Expected from English Teachers}

In this case, USHs perceived positively English teachers who were: punctual, closed to their students, dedicated to their jobs, not discriminating their students, and understand their students' characters. However, USMs did not completely agree with those USHs' ideas. There were only three English teachers' social attributes which both of the groups perceived positively, i.e.: being closed to their students, not discriminating their students, and understanding their students' characters. The other two social attributes USMs expected from their English teachers but were not perceived positively by USHs were diverting and cooperative.

However, English teachers' social attribute mentioned the last, i.e.: cooperative was also perceived positively by USLs even they put it in the second rank. Besides, USLs admired English teachers who cared their students, were dedicated to their job, and understood their students' characters. From the description above, the researcher found that there were only two English teachers' social attributes, i.e.: being closed to their students and understanding their students which were positively perceived by all university students although they had different reasons and different ranks. Then, the English teachers' social attributes admired by USHs and USMs were treating (not discriminating) their students equally, being closed to their students and understanding their students' characters. In addition, English teachers' social attributes positively perceived by USMs and USLs were being cooperative and understanding their students' characters. And the last, English teachers' social attribute USHs and USLs liked was being dedicated to their jobs.

As stated above, English teachers' social attributes perceived positively by all groups were only being closed to their students and understanding their students' characters. The first social attribute mentioned above even was put in the first rank by USLs, in the second rank by USHs, and in the fourth one by USHs. Though they put this social attribute in different ranks, they had similar reasons. All of them claimed that being closed to their students, English teachers could communicate with their students better.

In turns, the students would feel free to ask the lessons they had not understood well and the teachers were willing to answer them. By having such a good relation, students would easily reach a better academic achievement. This also happened to the second English teachers' social attribute, i.e.: understanding their students' characters. All the groups put it in the fifth rank and claimed that by understanding their students' characters, the teachers would know their students' interest and the way to study. These two things would be able to help the students increase their academic achievement.

Besides those two English teachers' social attributes, there were the other two attributes positively perceived by at least two groups of informants. Those were being cooperative with their students and dedicated to their jobs. The first attribute was perceived positively by the groups of USLs and USMs. Even they put it in the second rank. It means that this attribute was considered important because by being cooperative with the students, the teachers could guide their students academically and the students could get advantages from the teachers' guidance. Then, the second attribute, i.e.: being dedicated to their jobs was put in the third rank by USHs and in the fourth by USLs. In this case, all of those two groups argued that this attribute could help the students in facing their difficulties in studying English.

However, SSHs expected to have English teachers who were: caring about their students, not discriminating their students, being closed to their students, understanding their students' characters, and always having fun with their students. The English teachers' social attributes claimed by SSHs above were believed to be able to help the students increase their English proficiency. However, they were not completely perceived by SSMs and SSLs. There were only three of them which were also expected by SSMs, i.e.: being closed to their students, treating their students equally, which SSHs called not discriminating their students, and understanding their students' characters and there were also three which were supported by SSLs, i.e.: being closed to their students, treating their students equally, which SSHs called not discriminating their students, and caring about their students.

Based on the presentation above, being closed to their students was positively perceived by all groups though they put it in different ranks but they had similar reasons. SSLs and SSMs put it in the first rank because they thought 
that by being closed to their students, the teachers were willing to give their students opportunities to ask what they had not understood and the students did not hesitate to use these opportunities. Then, these could help the teachers know the students' weaknesses and found appropriate strategies to improve their teachings. Though SSHs put this attribute in the third rank, they still had a similar reason, i.e.: the teachers were willing to meet their students after the class and gave some explanations needed by their students. Finally, those three groups agreed that the students could increase their English proficiency if they were closed to their teachers.

The English teachers' second social attribute highly appreciated by all the three groups was treating their students equally. SSLs and SSHs put this social attribute in the second rank while SSMs in the third rank. Though they put it in different ranks, they had the same reason and objective, i.e.: Principally all students did not want to be discriminated. They claimed that if the teachers treated them equally, at the same time the teachers built students' belief which could increase their motivation to study.

Finally, this motivation could increase their academic success. Another English teachers' social attribute positively perceived by SSHs and SSLs was caring about their students. This attribute was put in the first rank by SSHs and in the third by SSLs. Their choice was determined by their idea that this attitude could help them understand their students' interest and needs. In turns, these interest and needs would be able to lead the teachers to explain the lessons better.

\section{The Leadership Attributes the Students Expected from English Teachers}

USHs expected their English teachers to have leadership attributes as follows: capable to control their class, able to empower their students, able to guide their students to a better study environment, steadfast in challenging the students' poor behavior, and ready to take risks. However, USMs did not completely agree with those USHs' ideas and the ranks as well. The only one teachers' leadership attribute which was not positively perceived by USMs was ready to take risks. Instead, they preferred to have English teachers who were able to align their teaching with the schools' goals. When the teachers' leadership attributes chosen by USHs and USMs were compared to those chosen by USLs, the researcher could say that there were three out five teachers' leadership attributes which were the same. Those were: capable to control their class, able to overcome their students' misbehavior and able to bring their students to a better study environment.

Then, SSHs expected to have English teachers who: have good class management, can create better study environment, can empower their students knowledge and skills, can overcome the students' misbehavior, and can motivate their students to be independent. These attributes were believed to be able to help the students increase their English proficiency. However, teachers' leadership attribute, i.e.: empowering their students' knowledge and skills was not expected by SSMs and overcoming the students' misbehavior was not admired by SSLs.

\section{The Classroom Interaction Attributes the Students Expected from English Teachers}

USHs expected their English teachers to have classroom interaction attributes as follows: being creative in using various ways to attract their students' attention in their teaching activities, consistent in using correct English in their teaching activities, always motivating their students to communicate with others in English, criticizing the students' academic performance and providing them with relevant and useful feedback, and giving their students opportunities to explain their mistakes. Though USMs completely agreed with those USHs' ideas, they put them all in different ranks. When those attributes were compared to those chosen by USLs, it was found that there were four out of five attributes were the same. The only one attribute which was positively perceived only by USLs but not by USHs and USMs was guiding the students to behave appropriately in the classrooms.

Then, SSHs expected to have English teachers who: enforced the students to communicate with other students in English, used various teaching methods, and used good English in all teaching activities. Though these English teachers' attributes were claimed by SSHs to be able to help the students increase their English proficiency, they were not positively perceived by SSMs and SSLs. There were four of them which were also expected by SSMs and SSLs. The only one teachers' attribute which was expected by SSLs but not by SSHs and SSMs was guiding their students to behave appropriately in the classrooms. In addition, though most of the teachers' attributes were perceived positively by all groups of senior high school students, some were put in different ranks.

\section{Discussion}

When the English teachers' professional attributes were seen from the students' levels of educations, it was found out that principally all university and senior high school students had the same perceptions on them. The only difference they had was that the university students' reasons were more complete than the senior high school students'. In this case, the university students thought that seminars on English language and teaching could be beneficial for English teachers if they took parts in those seminars as the presenters not as listeners. This condition could be understood because university students had broader understandings on this topic than the senior high school students did.

The situation above also happened when the English teachers' professional attributes were seen from the students' levels of English proficiencies. The cleverer the students were the more logic their reasons were. For an example the 
students of senior high schools and those of universities having high English proficiency claimed that professional trainings were very important for English teachers because those trainings could help them be more professional in their teaching. Then, their professional teachings were believed to be able to motivate their students to study harder. In turns, it could help their students reach better English proficiency.

Besides those mentioned above, all students had the same perceptions. They expected their English teachers to take professional trainings such as: attending seminars and workshops on English language and literature and on English language teaching, sitting in their senior English teachers' classes in order to observe how they presented English lessons and continuing their education to improve their English knowledge and language teaching skills. This was because those activities were believed to have positive effects on their teaching practices and students' learning outcomes (Porter et al., 2003; King \& Newmann, 2004; Mundry, 2005; Quick et al., 2009; Hunzicker, 2010; and Moreno, 2010 \& Liakopoulou, 2011).

In addition, those trainings were even considered to be vital for the English teachers (Stronge, 2007) because the trainings could help them learn new strategies to be applied in the teaching and learning processes. Some other researchers proved that by joining these kinds of academic activities, the teachers would possess academic qualifications and professional knowledge required in teaching English (Moreno, 2010 \& Liakopoulou, 2011) such as pedagogical knowledge that could significantly contribute to the better understanding of students (Cubukcu, 2010 \& Moreno, 2010).

Then, these professional trainings were also believed to be able to make English teachers more creative in their teaching because they could implement various teaching methods as stated by Liakopoulou (2011) and they could positively affect their students' learning outcomes as found by Porter et al. (2003) and by Hunzicker (2010). This was because the teachers chose a specific teaching method which was suitable with the way their students learn. In order to be able to choose those teaching techniques and strategies that were most suitable with the students' way of learning, the teachers needed to know the kinds of knowledge that would enable them to observe their students (see: Darling and Baratz, 2005 \& Cubukcu, 2010). Then, this study proved that the teachers' teaching creativity could avoid the students' boredom in attending their English teachers' classes. In other words this teaching creativity would be able to increase their students' desire to study harder as it was found by Cubukcu (2010).

The last but not least, the participants thought that these professional trainings were important not only for novice English teachers but also for experienced ones as long as the trainings could give them good examples of English teaching or teaching practices (see: Porter et al., 2003; Mundry, 2005; Quick et al., 2009 \& Hunzicker, 2010), could empower all English teachers in their teaching, could meet their academic needs (see: King and Newmann, 2004; Moreno, 2010 \& Liakopoulou, , 2011), could involve them actively in the discussion for active learning was believed to be able to support their attention and memory as stated by Tate (2009), and all presenters were willing to share their teaching experiences. However, Sokal et al. (2003) found that novice and experience teachers put the classroom management as the highest priority on their objective. This was because they thought that the classroom management was needed to promote the students' motivation, enthusiasm and learning.

However, if the novice teachers could not take these trainings, they were suggested to invite their more senior lecturers come to their English classes to watch how they taught English or they could sit in their more senior English lecturers' classrooms to get important and useful feedbacks (see: Liakopoulou, 2011). Then, experienced teachers were believed to be able to increase their students' desire to study harder as found by Cubukcu, (2010) if the teachers gave them enough encouragement and positive. If the feedbacks were accepted by the colleagues, the teacher learning would be strengthened (see: Lambert et al., 2007 \& Lieberman and Pointer, 2008).

Besides, the participants claimed that English teachers could increase their professionalism in their teaching by reading books, scientific articles, and journals of language and language teaching or by watching videos by which they could acquire professional knowledge needed in teaching English (see: Liakopoulou, 2011) and by imitating how successful teachers are performing in their English classes. By then they were expected to be able to teach their students more successfully. However, it did not mean that they might forget to take their higher education in English Language Teaching so that they could prepare their English teaching materials and transfer them to their students. Those descriptions above appeared the same when the teachers' professional attributes were seen from the students' levels of English proficiencies. It means that all senior high school and university students from all levels of English proficiency had the same idea as described above.

Furthermore it is believed that teachers' effectiveness in their teaching depends not only on their knowledge and skills (Rockoff et al., 2008) but also on their personality (Polk, 2006; Khojastehmehr and Takrimi, 2009; Moreno, 2010 \& Liakopoulou, 2011). This teachers' effectiveness becomes very important because it can influence the students' academic achievement (Rice, 2003; Polk, 2006; Danili and Reid, 2006; Goe, 2007; Rockoff et al., 2008 \& Moreno, 2010). When the students' perceptions on the English teachers' personality attributes were compared based on the students' levels of educations, it was found that there were three English teachers' personality attributes which were highly expected by university students but not by senior high school students, i.e.: being resourceful, well-prepared and enthusiastic. The difference was caused by their academic needs. Since university students needed more English knowledge, information and explanation, they expected much to have English teachers who had those three attributes. 
Then, when the students' perceptions on the English teachers' personality attributes were discussed based on the students' levels of English proficiencies, it was found that the students having high English proficiency expected much to have English teachers who were well-prepared because these students needed comprehensive explanation and discussion. Then, the students with mediocre English proficiency admired to have motivating English teachers because they needed to be motivated in order to be able to compete with their cleverer colleagues. The last one was that the students having low English proficiency expected to have humorous English teachers because they claimed that it was easier for them to understand the lessons when their teachers made jokes.

Besides that, all students had the same perceptions. The university and senior high school students mostly perceived English teachers who were highly qualified, communicative, creative, motivating and humorous. Those all five English teachers' personality attributes were believed to be able to help the students reach better academic achievements, i.e.: English proficiency (Polk, 2006; Danili and Reid, 2006; Goe, 2007 \& Rockoff et al., 2008).

In more detailed, being highly qualified was mostly perceived by the students because English teachers, according to them, had to be able to prepare the lesson plans (Darling and Baratz, 2005), to select and present teaching materials (Wayne and Young, 2003), to prepare teaching aids, to construct tests, to evaluate and to give feed-backs on the students' work (Gurney, 2007). The ideas above were supported by Cubukcu's study (2010) which said that high quality teachers had to be able to apply various instructional methods in their classrooms to fulfill their students' learning needs, to create good studying environment and to motivate their students to study the language (Moreno, 2010). All those academic activities were believed to be able to increase the students' English proficiency.

Then, the English teachers' second personality attribute, i.e.: being communicative was highly perceived by the students because they claimed that in order to help them get better English proficiency, English teachers should be communicative. Some studies had proved that this Personality Attribute was included as one of teachers' personality traits which could build effective and quality teachers. Besides, this teachers' personality attribute could help the students reach better academic achievements. (Danili and Reid, 2006; Polk, 2006; Goe, 2007; Douglas and Routledge, 2007; Khojastehmehrs and Takrimi, 2009; Richardson and Arker, 2010 \& Kneipp et al., 2010).

In this case, communicative teachers were believed to be able to explain the lessons systematically (Wayne and Young, 2003 \& Brown, 2004), even they had to be able to explain very complicated teaching materials in such a way so that their students could understand them more easily (Wayne and Young, 2003; Danili and Reid, 2006 \& Rockoff et al., 2008). Then, if the students had difficulties in catching the teachers' explanation, the teachers should be willing to listen to their students' educational problems and to explain the lessons clearly and systematically. In other words, communicative teachers were those who could present difficult lessons to their students successfully using various methods of teaching. Furthermore in order to be communicative, novice teachers were recommended to improve their teaching skills by asking their more experienced colleagues and or sitting in their classes so that they could get feedbacks on the ways they were teaching English. Besides, they could also ask someone to record them on a videotape while they were teaching English in the classrooms.

The following English teachers' personality attribute which the students highly perceived was being creative in selecting and developing teaching materials and in using various teaching methods. This was because the students thought that English teachers who wanted to help their students understand English lessons easily, they had to be creative in selecting and developing teaching materials so that their students were interested in the subject they were teaching. If the students could understand the lessons easily, they would be able to reach a better grade in English (Polk, 2006; Danili and Reid, 2006 \& Rockoff et al., 2008). Besides, the creative English teachers were believed to be able to use various teaching methods (Wayne and Young, 2003) to maintain their students' interest in English lesson. In other words, in order to make themselves interested in their teachers ' explanation, the students needed English teachers with various methods of teaching (Wayne and Young, 2003). Then, this good explanation was expected to be able to help them understand all teaching materials very well (Polk, 2006; Danili and Reid, 2006 \& Rockoff et al., 2008).

The English lecturers' next personality attribute highly perceived by the students was being motivating. The students claimed that they were willing to study English more and more if their teachers were motivating, used various teaching methodologies and managed their classrooms wonderfully (Moreno, 2010 \& Halawah, 2011). Then, this attribute was considered important for English teachers because the students needed to work hard when they were given assignments and positive feedbacks by their teachers. Besides, these two things were believed to be able to build the students' beliefs in attaining better academic achievements because they could help the students know which parts of the students' home-works were wrong and which ones were right. Then, the students also claimed that their academic success was determined not only by the teachers' English knowledge (King and Newmann, 2004; Polk, 2006; Danili and Reid, 2006; Rockoff et al., 2008 \& Moreno, 2010) but also by their teachers' effectiveness in motivating them to study English more seriously (Moreno, 2010). This motivation could also, besides what had been explained above, be built by giving rewards to the students who had successfully done their home-work or English tests.

The English teachers' last personality attribute highly perceived by students was being humorous. It was believed that humor in the teaching and learning processes played a significant role in conveying the lessons (James, 2007) because laughter was a highly effective way to stimulate communication (Lovorn, 2008) which was believed to be able to help the teachers explain the lessons well and to increase learning speed (Torok, et. al., 2004). This idea was supported by Garner (2005) that humor could rouse student pleasure in learning and reducing anxiety. However, the 
students reminded English teachers that the teaching would be effective and remembered in relatively long time by the students when they were explained by high quality teachers with appropriate humors. That was why being humorous was considered as one of the best personality attributes that contributed to teacher effectiveness but if the teacher humor demeaned the students, they would consider it as inappropriate (Frymier, et al., 2008).

When the students' perceptions on the English teachers' social attributes were also compared based on the students' levels of educations, the researcher found that there were only two attributes admired by university students but not by senior high school students, i.e.: being punctual and dedicated. These perceptions were influenced by their high expectation to their English teachers and by their knowledge on the foreign cultures. That is why they expected their English teachers always came to the class on time to teach them and gave more priority to their academic progress.

Then, when their perceptions were compared based on their levels of English proficiencies, it was found that the students with high English proficiency expected much to study with English teachers who were academically fair to all of their students. This was because they did not want their English teachers to evaluate their tests unfairly. If it happened all the time, the students would lose motivation to study more seriously. Then, the students with mediocre English proficiency expected to have cooperative English teachers because they were believed to be able to communicate their lessons to their students much more easily. The last one was that the students with low English proficiency expected to study with humorous English teachers because they claimed that it was easier for them to understand the lessons when their teachers sometimes made jokes.

Besides that, all students had the same perceptions on the English teachers' social attributes as described below. They all perceived English teachers who were closed to them, always treated them equally, understood their characters, were cooperative with them and cared about them. The sentence above means that being closed to their students was the English teachers' social attribute which was mostly perceived positively by the students. It can be understood because they thought that closed or positive teacher-student relationships could make the students feel safe and secure in their learning environments and support their social and academic skills (Wentzel, 2009 \& Moreno, 2010).

Besides, these closed relations were believed to be able to motivate the students to learn (Moreno, 2010). This students' motivation was said to be another factor that could influence the students' social and academic outcomes (Wentzel, 2009). Other educational researchers such as: Roorda et al. (2011) and Spilt et al. (2011) found that closed relationship between relationship the teachers and students could influence the learning environment (Pianta et al., 2003 \& Moreno, 2010) which in turns could affect the students' academic motivation (Becker and Luthar, 2002; Pianta et al., 2003; Stipek, 2004; Moreno, 2010 \& Raufelder et al., 2013). In addition, a motivational theorist, Wentzel (2009), claimed that the students' perception of their relationship with their teachers had an important role in motivating the students to attain better academic achievements.

When the students' perceptions on the English teachers' leadership attributes were compared based on the students' levels of educations, it was found that there was only one attribute positively perceived by university students but not by senior high school students, i.e.: always helping them understand their duties and responsibilities. This perception was influenced by their awareness of having so many academic duties and responsibilities and co-curricular activities. On the other hand, there was also one attribute which was highly expected by senior high school students but not by university students, i.e.: creating better study environment. This perception was much influenced by their expectation that they needed the class where they could study more comfortably.

Then, when the students' perceptions on the English teachers' leadership attributes above were compared based on the students' levels of English proficiencies, the researcher found that the three groups of students had only one different perception. The students with high English proficiency preferred to study with English teachers who were ready to take risks. It means that they expected their English teachers always tried something new with their English teaching and they might not be afraid of being failed in their teaching experiment. Then, the students having mediocre English proficiency chose to study with English teachers who were able to align their teaching with the schools' goals. It means that the English teachers should dare to refuse explaining the additional teaching materials which were not in line with the syllabus of each subject. The last, the students having low English proficiency preferred to have English teachers who could help them understand their duties and responsibilities.

On the contrary, all students had the same perceptions on their English teachers' leadership attributes. They all expected to have English teachers who were able to manage the classes, guided them to a better study environment, overcome their misbehavior, motivated them to stand on their own feet, and helped them understand their duties and abilities. These mean that English teachers who were able to manage their classes are mostly admired by the students. Since teaching and learning a foreign language was considered as social process which required the teachers and the students' interaction in a social environment (Sariçoban, 2006), the teaching and learning process should be conducive (Wayne \& Young, 2003; Rockoff et al., 2008 and Khojastehmehr \& Takrimi, 2009).

When the perceptions were compared based on the students' levels of educations, it was found out that there was only one English teachers' classroom interaction attribute highly perceived by university students but not by senior high school students, i.e.: always giving them opportunities to explain their mistakes. Though university students needed their teachers' criticism on their academic performances, they thought that their teachers also needed to listen to their explanation about the mistakes they had made. On the contrary, the senior high school students expected to have 
English teachers who always gave them opportunities to practice their English. However, when they were compared based on their levels of English proficiencies, they had the same perceptions with different reasons.

In addition, all students positively perceived English teachers who were creative in attracting their students' attention on their teaching activities, always used correct English in their teaching activities, always motivated their students to communicate with others in English, provided their students with relevant and useful feedbacks, and always gave their students opportunities to explain their mistakes. Since different students might have different ways of learning English, English teachers should have various ways of teaching English so that all of their students would be interested in their teaching. In turns, this will help the students attain better English proficiencies.

\section{Conclusion and Recommendations}

\section{Conclusion}

Based on the discussion above, several propositions are put forward as follows: Firstly, the students' levels of educations do not much influence the students' perceptions on the teachers' professional attributes. The only important thing which makes their perceptions different is that the university students have more complete reasons due to their better understandings on those attributes. However, the students' levels of English proficiencies influence the students' perceptions. In this case, the students having high English proficiency present more logic reasons than the other two groups of students. Then, all of them agree that professional trainings are badly needed by English teachers in order to increase their English knowledge and language teaching skills.

Secondly, related to the English teachers' personality attributes, the students' levels of educations can color the students' perceptions on their English teachers' personality attributes. The higher the students' level of education is the more qualifications the students expect from their English teachers. In this case university students expect to have English teachers who are resourceful, well-prepared and enthusiastic. These three English teachers' personality attributes are believed to be able to help the students meet their academic needs.

Besides that, the students' levels of English proficiencies also influence the students' perceptions. In this case the cleverer the students are, the more serious English teachers are admired. This difference can be seen from their choice which can be described as follows: the students with high English proficiency expect to have English teachers who were well-prepared; those with mediocre English proficiency admire to have motivating English teachers and those with low English proficiency expect to have humorous English teachers.

Though the senior high school and university students have different perceptions on the English teachers' personality attributes, they still have similarities as described below. English teachers are said to be ideal by all senior high school and university students if they are qualified and communicative because the teachers with those two personality attributes are believed to be able to prepare and present the teaching materials to their students, to construct good tests, to evaluate the students' work precisely and to give feed-backs on their students' works.

Thirdly, related to the English teachers' social attributes, the students' levels of educations can influence the students' perceptions on their English teachers' social attributes. In this case, university students demand more qualifications to their English teachers, especially on their teaching discipline because their perceptions are influenced by English cultures that they have already learnt. These students expect to have English teachers who are always punctual to come to the class and dedicated to their job so that they can teach their students enthusiastically.

Besides that, the students' levels of English proficiencies also influence the students' perceptions on the English teachers' social attributes. The higher the students' English proficiency is, the more academic the students' reason is. It is implied by the students' perceptions on their English teachers' social attributes as follows: the students with high English proficiency expect their English teachers to be fair in their evaluation; the students with mediocre English proficiency choose to study with cooperative English teachers; and the students with low English proficiency expect to study with humorous English teachers.

Though the students from different levels of educations and of English proficiencies have different perceptions on the English teachers' social attributes, it does not mean that they do not have similarities. The followings are the English teachers' social attributes admired by the students seen from their different levels of educations. The senior high school and university English teachers are considered ideal when they are closed to the students and who understand their students' personality. This is because these two attributes are believed to be able to help them make their teaching environments better and motivate their students to learn English more.

Fourthly, related to the English teachers' leadership attributes, the students' levels of educations influence the students' perceptions on their English teachers' leadership attributes. In this case, the students' perception is much influenced by the students' academic awareness and expectation. It can be seen from the university students' expectation, i.e.: to have English teachers who can help them understand their duties and responsibilities and from the senior high school students', i.e.: to have English teachers who can create better study environment.

Besides that, the students' perceptions on the English teachers' leadership attributes are influenced by the students' levels of English proficiencies. The clever students' perception (English teachers who are ready to take risks) is influenced by their way of learning English, the average students' (English teachers who are able to align their teaching 
with the schools' goals) is influenced by their learning experience and the poor students' (English teachers who can help them understand their duties and responsibilities) is influenced by their limited English knowledge.

Out of those differences, all senior high school and university students who belong to the groups of high, mediocre and low English proficiencies still have similar perceptions on their English teachers' leadership attributes, namely: English teachers who can manage their classes and who can bring their students to a better study environment as ideal English teachers because those teachers are believed to be able to create conducive study environment in which the teaching and learning activities can flourish.

Fifthly, related to English teachers' classroom interaction attributes, the students' levels of educations can reflect the students' perceptions on these teachers' attributes. The higher their level of education they have, the higher their expectation they propose. In this case, university students expect to have mutual understanding and respect with their English teachers while senior high school students only expect to get more opportunities to practice their English. However, their levels of English proficiencies do not influence their perceptions on those attributes. Besides that, all senior and university students have some similar perceptions as described below. They claim that English teachers always use correct English in their teaching activities and always motivate their students to communicate with others in English as ideal teachers because those English teachers become models for their students.

\section{Recommendations}

In order to be admired by their students, English teachers are recommended to take professional trainings, to upgrade their English knowledge and language skills, to recognize the personality attributes that their students highly expect, to build good relationships with their students and to learn how to manage their English classes. Then, in order to be more successful in the teaching and learning processes, English teachers need to consider not only their students' levels of educations but also their students' levels of English proficiencies.

Furthermore, in order to reach more successful education in Indonesia, English teacher education institutions which are still small and have not got their institutional accreditation should provide high quality lecturers, good curriculum and education facilities and conduct some various English teachers trainings. Accordingly the Indonesian government, i.e.: Ministry of Research, Technology and Higher Education of the Republic of Indonesia always monitor and evaluate universities and institutions which establish and organize English and or English Education Departments. Besides, the lecturers who are involved in preparing English teachers, prioritize to introduce the teachers' attributes highly perceived by the students as found out in this research to the English teachers to be. This implies that all lecturers of English teacher education institutions should not only teach the teaching materials needed by their students but also apply those teachers' attributes in their teaching and learning activities.

The last one, in order to have more professional English teachers, teacher training centers are recommended to conduct professional trainings such as seminars on English language and language teachings, English workshops and international conferences which are believed to be able to help English teachers learn new strategies to be applied in their teaching and improve their academic qualifications and professional knowledge required in teaching English

\section{Acknowledgement}

The author would like to express their gratitude to State Polytechnic of Malang, Indonesia for the assistance and the information provided to ensure the success of the study.

\section{References}

[1] Becker, B. E. and Luthar, S. S. 2002. Social-Emotional Factors Affecting Achievement out- Comes among Disadvantaged Students: Closing the Achievement Gap. Educational Psychologist. 37 (4)

[2] Brown, D. 2003. Urban Teachers' Use of Culturally Responsive Management Strategies: Theory into Practice. Lawrence Erlbaum Associates (Taylor \& Francis Group)

[3] Brown, N. 2004. What Makes a Good Educator? The Relevance of Meta Programme. Assessment \& Evaluation in Higher Education, 29 (5)

[4] Cubukcu, F. 2010. Student Teachers' Perceptions of Teacher Competence and their Attributions for Success and Failure in Learning. Uluslararast Sosyal Ara tırmalar Dergisim The Journal of International Social Research. 3 (10)

[5] Danili, E. and Reid, N. 2006. Cognitive Factors that can Potentially Affect Pupils' Test Performance. Chemistry Education Research and Practice, 7 (2)

[6] Darling, H. L. and Baratz, S. J. 2005. A Good Teacher in Every Classroom: Preparing the Highly Qualified Teachers our Children Deserve. San Francisco, CA: John Wiley

[7] Frymier, A. B., Wanzer, M. B. and Wojtaszczyk, A.M. 2008. Assessing Students' Perceptions of Inappropriate and Appropriate Teacher Humor. Communication Education, 57 (2)

[8] Garner, R. 2005. Humor, Analogy and Metaphor: H.A.M. it up in Teaching. Radical Pedagogy, 6 (2) 
[9] Goe, L. 2007. The Link between Teacher Quality and Student Outcomes: A Research Synthesis. Washington, DC: National Comprehensive Center for Teacher Quality. Retrieved from http://www.tqsource.org/publications/teacherEffectiveness.php

[10] Gurney, P. 2007. Five Factors for Effective Teaching. New Zealand Journal of Teacher's Work, 4 (2).

[11] Halawah, I. 2011. Factors Influencing College Students' Motivation to Learn from Students' Perspective. Education, 132 (2)

[12] Hunzicker, J. 2010. Characteristics of Effective Professional Development: A Checklist. Characteristics of Effective Professional Development. Department of Teacher Education Bradley University.

[13] James, D. 2007. A Need for Humor in Online Courses. College Teaching, 52(3).

[14] Kennedy, M.M. 1997. Defining an Ideal Teacher Education Program. Michigan State University, NCATE.wpd

[15] Khojastehmehr, R. and Takrimi, A. 2009. Characteristics of Effective Teachers: Perceptions of the English Teachers. Journal of Education \& Psychology, 3 (2).

[16] King, B. and Newmann, F. 2004. Key link: Successful Professional Development must Consider School Capacity. Journal of Staff Development, 25 (1)

[17] Kneipp, L. B., Kelly, K. E., Biscoe, J. D. and Richard, B. 2010. The Impact of Instructor's Personality Characteristics on Quality of Instruction. College Student Journal, 44 (4)

[18] Lambert, M., Wallach, C. and Ramsey, B. 2007. The Other Three R's: Small Schools Project Examines Instructional Change through Relationships, Relevance, and Rigor. Journal of Staff Development, 28 (4)

[19] Liakopoulou, M. 2011. The Professional Competence of Teachers: Which Qualities, Attitudes, Skills and Knowledge Contribute to a Teacher's Effectiveness? International Journal of Humanities and Social Science, 1 (21)

[20] Lieberman, A. and Pointer, M.D. 2008. Teacher Learning: The Key to Education Reform. Journal of Teacher Education, 59 (3)

[21] Lovorn, M.G. 2008. Humor in the Home and in the Classroom: The Benefits of Laughing While We Learn. Journal of Education and Human Development, 2 (1)

[22] Moreno, R. C. 2010. Effective Teachers -Professional and Personal Skills. ENSAYOS, Revista de la Facultad de Educación de Albacete, 24

[23] Mundry, S. 2005. Changing Perspectives in Professional Development. Science Educator, 14 (1)

[24] Okoro, C.O. and Chukwudi, E.K. 2011. The Ideal Teacher and the Motivated Student in a Changing Environment. Journal of Educational and Social Research. 1 (3)

[25] Onike, R. 2010. Teacher as a Key Factor Affecting Learning, The Wryte Stuff Writers' Community. Oyo: Anikab

[26] Pianta, R. C., Hamre, B. K. and Stuhlman, M. W. 2003. Relationships between Teachers and Children. In W. M. Reynolds, \& G. E. Miller (Eds.), Educational Psychology. Comprehensive Handbook of Psychology, 7. New York: Wiley

[27] Polk, J. A. 2006. Traits of Effective Teachers. Arts Education Policy Review, 107 (4)

[28] Porter, A., Garet, M., Desimone, L. and Birman, B. 2003. Providing Effective Professional Development: Lessons from the Eisenhower Program. Science Educator, 12(1)

[29] Quick, H., Holtzman, D. and Chaney, K. 2009. Professional Development and Instructional Practice: Conceptions and Evidence of Effectiveness. Journal of Education for Students Placed at Risk (JESPAR), 14(1).

[30] Raufelder, D., Bukowski, W.M. and Mohr, S. 2011. Thick Description of the Teacher-Student Relationship in the Educational Context of School: Results of an Ethnographic Field Study. Journal of Education and Training Studies, Vol. 1, No. 2; October 2013 ISSN 2324-805X E-ISSN 2324-8068 published by Redfame Publishing URL: http://jets.redfame.com

[31] Rice, J. K. 2003. Teacher Quality: Understanding the Effectiveness of Teacher Attributes. Washington, DC: The Economic Policy Institute

[32] Richardson, R. C. and Arker, E. 2010. Personalities in the Classroom: Making the Most of them. Kappa Delta Pi Record, 46 (2)

[33] Rockoff, J.E., Jacob, B.A., Kane, T.J., and Staiger, D.O. 2008. Can you Recognize an Effective Teacher when you Recruit one? NBER Working Paper 14485

[34] Roorda, D. L., Koomen, H. M. Y., Spilt, J. L., and Oort, F. J. 2011. The Influence of Affective Teacher-Student Relationships on Students' School Engagement and Achievement: A Meta-Analytic Approach. In Revision for Publication in Review of Educational Research

[35] Sarıçoban, A. 2005. Classroom Management Skills of the Target language Teachers. Journal of Language and Linguistics Studies, 1 (1)

[36] Spilt, J. L., Koomen, H. M. Y. and Thijs, J. T. 2011. Teacher Wellbeing: The Importance of Teacher-Student. Relationships Education Psychology. 23 (4)

[37] Stipek, D. J. 2004. Teaching Practices in Kindergarten and First Grade: Different Strokes for Different Folks. Early Childhood Research Quarterly, 19 (4)

[38] Stronge, J. H. 2007. Qualities of Effective Teachers (2 ${ }^{\text {nd }}$ edition). Alexandria, VA: Association for Supervision \& Curriculum Development 
[39] Tate, M. L. 2009. Workshops: Extend Learning beyond your Presentation with these Brain- Friendly Strategies. Journal of Staff Development, 30 (1):

[40] Torok, S.E., McMorris, R. F., and Lin, W. C. 2004. "Is Humor an Appreciated Teaching Tool? Perceptions of Professors" Teaching Styles and Use of Humor." College Teaching, 52 (1)

[41] Wayne, A. M., and Youngs, P. 2003. Teacher Characteristics and Student Achievement Gains: A Review. Review of Educational Research, 73 (1)

[42] Wenglinsky, H. 2000. How Teaching Matters: Bringing the Classroom Back into Discussions of Teacher Quality. Princeton, New Jersey: The Milken Family Foundation and Educational Testing Service

[43] Wentzel, K. R. 2009. Students' Relationships with Teachers as Motivational Contexts. In K. R. Wentzel, and A. Wigfield (Eds.), Handbook of Motivation at School, New York, NY: Routledge 